\title{
Depression and Quality of Life in Mothers of children with Pervasive Developmental Disorders ${ }^{1}$
}

\author{
Maria Ângela Fávero-Nunes ${ }^{2}$ \\ Manoel Antônio dos Santos ${ }^{3}$
}

The aim of this study was to evaluate the prevalence of dysphoria/depressive symptoms in mothers of autistic children and to identify correlations between quality of life and sociodemographic profile. An exploratory, descriptive and cross-sectional study was carried out, involving 20 mothers, by applying a socio-demographic profile questionnaire, the Brazilian version of the Beck Depression Inventory (BDI) and the WHOQOL-Bref quality of life scale. Dysphoria/depression criteria were found in $15 \%$ of the mothers. Overall quality of life was evaluated as positive in $70 \%$, however only $40 \%$ were satisfied with their health. The Physical domain (mean=69.4) was perceived as the best, and environment domain as the worst (mean=60.8). Quality of life had a positive association with family income and level of education, and a negative association with depression. Considering the results, further research, especially on those variables that were not statistically relevant, is suggested.

Descriptors: Mother-Child Relations; Child; Autistic Disorder; Depression; Quality of Life.

\footnotetext{
${ }^{1}$ Supported by Fundação de Amparo à Pesquisa do Estado de São Paulo - FAPESP, Process \#02/11665-9.

2 Psychologist, Doctoral Student, Instituto de Psicologia, Universidade de São Paulo, e-mail: faveroma@usp.br, faveroma@hotmail. com.

${ }_{3}^{3}$ Psychologist, Faculty, Faculdade de Filosofia, Ciências e Letras de Ribeirão Preto, Universidade de São Paulo, Brazil e-mail: masantos@ ffclrp.usp.br.
}

Corresponding Author:

Maria Angela Favero-Nunes

Rua Lafaiete, 1976 Apto 18

Vila Seixas

CEP: 14015-080 Ribeirão Preto, SP, Brasil

E-mail: faveroma@usp.br 


\section{Depressão e qualidade de vida em mães de crianças com transtornos invasivos do desenvolvimento}

O objetivo do estudo foi avaliar a prevalência de disforia/sintomas depressivos em mães de crianças com transtorno autístico e identificar possíveis relações com qualidade de vida e características sociodemográficas. Trata-se de estudo exploratório, descritivo e transversal, conduzido com 20 mães, por meio da aplicação de questionário do perfil sociodemográfico e da versão brasileira do Inventário de Depressão de Beck (BDI) e da forma abreviada da Escala de Qualidade de Vida WHOQOL-Bref. Os resultados mostraram que $15 \%$ das mães preencheram os critérios para disforia/depressão; $70 \%$ avaliaram favoravelmente sua qualidade de vida global, todavia, apenas $40 \%$ delas estavam "satisfeitas" com sua saúde. O domínio físico (média=69,4) foi o melhor apreciado e o pior foi o ambiental (média $=60,8$ ). A qualidade de vida se associou positivamente com renda familiar e nível de instrução e, negativamente, com depressão. Considerando-se os resultados obtidos, são sugeridos novos estudos que aprofundem, especialmente, as variáveis que não se mostraram significativas.

Descritores: Relações Mãe-Filho; Criança; Transtorno Autístico; Depressão; Qualidade de Vida.

\section{Depresión y calidad de vida en madres de niños con trastornos invasores de desarrollo}

El objetivo del estudio fue evaluar la prevalencia de disforia/síntomas depresivos en madres de niños con trastorno autístico e identificar posibles relaciones con calidad de vida y características sociodemográficas. Se trata de estudio exploratorio, descriptivo y transversal, conducido con 20 madres, por medio de la aplicación de cuestionario del perfil sociodemográfico y de la versión brasileña del Inventario de Depresión de Beck (BDI) y de la forma abreviada de la Escala de Calidad de Vida WHOQOL-Bref. Los resultados mostraron que $15 \%$ de las madres llenaron los criterios para disforia/ depresión; 70\% evaluaron favorablemente su calidad de vida global, sin embargo, apenas $40 \%$ de ellas estaban "satisfechas" con su salud. El dominio físico (promedio $=69,4$ ) fue el mejor apreciado y el peor fue el ambiental (promedio $=60,8$ ). La calidad de vida se asoció positivamente con la renta familiar y el nivel de instrucción y, negativamente, con la depresión. Considerándose los resultados obtenidos, se sugiere que sean realizados nuevos estudios que profundicen, especialmente, las variables que no se mostraron significativas.

Descriptores: Relaciones Madre-Hijo; Niño; Trastorno Autístico; Depresión; Calidad de Vida.

\section{Introduction}

The psychosocial impact produced when the family becomes aware of the existence of a developmental disorder in the child is amply documented in the literature ${ }^{(1)}$. A recent study with 20 mothers of children with pervasive developmental disorder showed that special attention is needed regarding how health professionals communicate this information to parents ${ }^{(2)}$. That investigation concluded that the disorder is being diagnosed after the recommended age, that the first characteristic signs are principally perceived by the mother and that child health professionals may not be aware of the importance of early detection of the disorder, which would minimize present and future negative effects.

Individuals with pervasive developmental disorder (PDD), such as autistic disorder, have severe 
impairments in the development of social interaction skills, communication and the presence of stereotypical behavior, interests and activities ${ }^{(3)}$. The manifestation of the disorder usually occurs in the first years of life and is frequently associated with some degree of mental retardation. Approximately two thirds of these children are permanently unable to live independently and only one third can achieve any degree of personal autonomy as adults ${ }^{(4)}$, which implies a high workload and ongoing concern for the caregiver.

Recent studies have looked at the psychological assessment of individuals with developmental disorder and their families, especially in the case of autistic disorder. Families need to change schedules and routines, they need to make time to access therapeutic services and bear the financial costs of transporting the child to and from these services. These factors may affect the way parents deal with the child, creating the possibility of adverse effects on the relationship between family members ${ }^{(5)}$.

In research published recently in a North American journal, 282 caregivers of adults with behavioral problems were interviewed, such as Down syndrome and autism( ${ }^{(6)}$. The results indicated a lower psychological well-being reported by caregivers of adults with autism, concluding that they demonstrated more adjustment problems and stress than caregivers of people with Down syndrome.

In the Brazilian context, families containing individuals aged 5 to 15 years either with autistic disorder, with Down's syndrome or healthy were evaluated, concluding that the attention required from parents, due to the severity of symptoms in children with autistic disorder, raises stress in the family system, which is significant when compared to families of children with other disorders ${ }^{(7)}$. In another study, when comparing the well-being and stress levels of North American mothers of adolescents aged 15 to 16 years old with autistic disorder and Down syndrome, mothers of children with autistic disorder showed lower psychological well-being than the comparison group ${ }^{(8)}$.

Taking as its focus the issue of maternal mental health and the relationship established with the child since birth, a study with 429 Brazilian infants up to 20 days old showed that children of women with symptoms of postpartum depression are at increased risk of early cessation of breastfeeding. This suggests that depressive episodes interfere with the affective maternal state and can influence the quality of the bond between mother and $\operatorname{child}^{(9)}$.

Depression is associated with a disability that affects the surroundings, which includes the spouse and children. In a recent study with Chilean couples where the wives were depressed, it was observed that the women gave a more negative evaluation of the quality of family life and marital relationship, suggesting that these results could be explained by the depression in the women ${ }^{(10)}$.

In the area of health, quality of life is defined as individuals' perception about their position in life in the context of the culture and value system they live in and in relation to their objectives, expectations, standards and concerns ${ }^{(11)}$. Two aspects are relevant in the conceptualization of quality of life, which started to become stronger in the 1990s among scholars of the construct: subjectivity and multidimensionality. These refer, respectively, to the individuals' own perception about their state of health and non-medical aspects of their life, and how they assess their personal situation in the physical, psychological, social and environment dimensions related to their quality of life(12).

Concerning publications about the quality of life construct, the Latin American Journal of Nursing is a reference today. Recent research has sought to understand the quality of life and associated factors of 100 nurses in a Chilean hospital, applying the quality of life scale WHOQOL-Bref and a bio-socio-demographic questionnaire(13). The best domain assessed was the social relationships domain and the worst was the physical.

Aiming at integration of data on quality of life and depressive symptoms in specific populations, a recent study evaluated 68 nursing residents from the first and second years of residency in all areas of specialty ${ }^{(14)}$. The SF-36 instrument was used to assess the quality of life and the Beck Depression Inventory (BDI) to assess dysphoria/depression. There was a prevalence of dysphoria/depression in $27.9 \%$ of participants and an impairment of the mental component of quality of life.

However, so far as is known to date, there are few publications in national and international literature that relate depression and quality of life in family caregivers of children with autism spectrum disorders ${ }^{(1)}$. A recent study compared the quality of life evaluated subjectively by siblings of patients with autistic disorder and siblings of patients with speech problems, excluding from the sample those with a history of clinical or psychiatric illnesses and with disabilities (visual, auditory or motor, cognitive and/or intellectual)(15). It was concluded that there was a lower subjective evaluation of quality of life for siblings of autistic patients compared with the control 
group, confirming an impaired quality of life for children aged 7 to 11 years due to the presence of a sibling with autism, which is worse than that of siblings of children with speech problems.

The aim of this study was to evaluate the quality of life and prevalence of dysphoria/depressive symptoms in mothers of children with autistic disorder and to identify possible correlations between the number of items marked in the BDI, the domains of quality of life (physical, psychological, social and environment relationships) and socio-demographic variables (age and educational level of the mother, marital status, family income, current occupation, religion and number of children).

\section{Method}

The design of this study was exploratory, descriptive and cross-sectional, describing the characteristics and relationships existing in conditions of the research reality. The population is described at a determined moment, with a focus on quantitative research. The ethical criteria in accordance with the standards required by the Declaration of Helsinki were followed. The study was approved by the Research Ethics Committee (process CEP FFCLRP-USP n 045/2002).

\section{Participants}

In order to carry out the data collection, contact was established with two clinical and educational institutions specialized in attending children and adolescents with autistic disorder. The first institution consists of an education, therapeutic and clinical public utility and offers service to 50 students (39 males, 11 females) during the early-morning and daytime periods. The institution offers evaluation, clinical diagnosis and medication control with a child psychiatrist, and psychopedagogical evaluation, educational, therapeutic and clinical services, for children and adolescents referred by health professionals and hospitals. The second institution is a public school focused on special education, covering segments of the school, clinic, research and prevention. Forty children and adolescents ( 28 males, 12 females) are attended there in the morning and afternoon periods. It offers multidisciplinary services for diagnostic screening, individual and group clinical care for the students, and family counseling.

The following inclusion criteria were established: mothers of male children (under 12 years) with autistic disorder, willing to participate in the study. Mothers with a history of clinical or psychiatric illness or with sensory, motor or cognitive impairments that might affect the application of the instruments were excluded from this sample.

The choice of mothers of male children was based on the observed prevalence in this specific population of children with autistic disorder, approximately three to four cases of boys for every girl with autistic disorder(16). Thus, this study involved only mothers of sons with autistic disorder.

Participants were selected based on a convenience sample. Concerning the sample composition procedure, it was observed that a total of 90 mothers attended the institutions. Based on the criterion "the mother of a child under 12", half the population was excluded. Of the remaining 45, 13 were mothers of girls and, by this criterion, were excluded. Therefore, 32 mothers were invited to participate in the study, but only 20 agreed to be interviewed.

\section{Instruments}

Socio-demographic Profile Questionnaire (SPQ): designed specifically for this study, consisted of nine items that aimed to describe the socio-demographic profile of participants: age and educational level of mother (and son with PDD), marital status, family income, current occupation (paid or not), religion (practicing or not), number of children.

Beck Depression Inventory (BDI): a self-assessment measure of depression widely used for both research and clinical purposes, translated into several languages and validated in various countries(17). The original 1961 scale consists of 21 items, including symptoms and attitudes whose intensity ratings vary from 0 to 3 . For discriminant analysis of the instrument validated in Brazil(18), specific (sadness, pessimism, sense of failure, guilt, low selfesteem, suicidal ideas, weight loss) and non-specific items (inhibition for work, sleep disturbances, fatigue, decreased libido) are considered. In non-clinical samples, such as the mothers of this study, one can consider the following cut-off points: up to 15 for normal or mild depression; 16 to 20 for dysphoria; more than 20 for depression ${ }^{(19)}$

World Health Organization Quality of Life (WHOQOLBref): the World Health Organization (WHO) has developed a scale of quality of life WHOQOL assuming that this concept is comprehensive and can be applied to various diseases and non-medical situations ${ }^{(11)}$. Satisfactory characteristics of internal consistency, discriminative, criterion related and concurrent validity 
and test-retest reliability were obtained, which makes this instrument a useful alternative for use in studies that purport to assess the quality of life in Brazil(20).

The WHOQOL group uses a concept for quality of life that emphasizes the perception of the evaluated respondent. The short form of the scale of quality of life WHOQOL-Bref has been validated in the Brazilian context(21). This instrument consists of 26 questions, subdivided into four domains: physical, psychological, social relationships and environment. At the beginning of the scale, there are two general questions of quality of life and the other 24 represent each of the facets that make up the original instrument WHOQOL-100. The 26 questions are scored using a five point Likert scale.

\section{Procedure}

Data collection was started after approval by the Research Ethics Committee and formal consent from the management of both care institutions were obtained. The respective mothers were contacted by telephone, during which they were invited to participate in the study. Once the consent of the participant was obtained, an individual interview was scheduled at the institutions.

During the preparation phase, a pilot study was carried out in order to verify the adequacy of the instruments for the proposed objectives, and to serve as a guide for possible changes needed in the collection procedure.

Regarding the psychiatric history of the participants, two additional questions were included in the meeting with each mother: the first investigated whether they had undergone psychiatric treatment and the second checked whether they had used antidepressive drugs. All participants responded negatively to both questions. No control using a specific instrument was performed, for example an operational interview, such as the SCID, for the detection of psychiatric disorders.

The socio-demographic questionnaire and standardized instruments were read together with the participant, following the application instructions (selfreport) recommended for each technique.

Data from the SPQ, BDI and WHOQOL-Bref were summarized in Microsoft Excel ${ }^{\circledR} 97$ and transported to the program Statistical Package for the Social Sciences for Windows - version 10.0.1. The results were evaluated using methods of descriptive statistics, tabulation of simple frequencies, means and standard deviations. For statistical verification of the relationship between the study variables, the non-parametric Spearman correlation coefficient was used. Differences were considered statistically significant when $p \leq 0.05$.

\section{Results}

According to the data described in Table 1, the average age of participants was approximately 39.5 years, while that of the children was 10.6 years. The majority of families consisted of two to three children, with the minimum of one child and the maximum of six children.

With respect to the mother's education, the average time of schooling was approximately 10 years. Seven respondents $(35 \%)$ had primary education (complete or incomplete), seven (35\%) high school (complete or incomplete) and six (30\%) higher education (complete or incomplete). Table 1 shows that one participant studied for only three years while, at the other extreme, another completed 15 years of study.

Table 1 - Distribution of mean values, standard deviation and range of the socio-demographic characteristics of study participants

\begin{tabular}{lccc}
\hline \multicolumn{1}{c}{$\begin{array}{c}\text { Socio-demographic } \\
\text { characteristics }\end{array}$} & Mean Score (SD) & Minimum & Maximum \\
\hline Mother's age (years) & $39.55( \pm 6.84)$ & 29 & 56 \\
Child's age (years) & $10.65( \pm 2.68)$ & 3 & 12 \\
Mother's education (years) & $9.85( \pm 4.25)$ & 3 & 15 \\
Income (minimum wages) & $1.54( \pm 1.06)$ & 0.42 & 4.58 \\
Number of children & $2.65( \pm 1.34)$ & 1 & 6 \\
\hline
\end{tabular}

Concerning marital status, 18 participants were married $(90 \%)$, one lived in a consensual union (5\%) and another was separated (5\%). A participant was considered a "working mother" when she would remain, at least part-time, in another place that was not her home, which occurred with only two participants (10\%) who performed paid work. Another two participants $(10 \%)$, one attending higher education and the other a post-graduate student, reported spending at least one of the periods away from home. Only two (10\%) received support from assistants to provide childcare.

The variable income per capita, calculated based on the minimum wage, averaged 1.54 , with disparity between the minimum and maximum income, since 4.58 salaries per person were calculated for one family, whilst for another only 0.42 was calculated. According to the criteria of socio-economic classification of the Brazilian Association of Research Companies(22) the participants are predominately classified at level C1 (60\%), followed by C2 (30\%) and B2 (10\%). 
Regarding religion, 11 participants (55\%) reported maintaining religious practice, seven reported having a religion, but did not attend worship services (35\%) and two reported not following any religion (10\%). The religions mentioned included: Catholic, Christian Congregation of Brazil, Christian, Evangelical and Spiritualist.

Only two children (10\%) were participating in the process of school inclusion, both enrolled in the second grade of elementary school. In both cases, they attended school in parallel with activities at the specialized institution.

Table 2 - Scores obtained with the Beck Depression Inventory from 20 mothers of children with autistic disorder

\begin{tabular}{lcc}
\hline Scores of Beck Depression Inventory & N & $\%$ \\
\hline$<15$ (normal) & 17 & 85 \\
$16-20$ (dysphoria) & 1 & 5 \\
$>20$ (depression) & 2 & 10 \\
Total & 20 & 100 \\
\hline
\end{tabular}

As can be seen in Table 2, 85\% of the mothers did not fulfill the criteria for depression, $5 \%$ met the criteria for dysphoria and $10 \%$ reported criteria consistent with depression, considering the cutoff points established by the scale. This index is equivalent to that found in the general population - around 5 to $10 \%{ }^{(23)}$. Four participants reported more than 10 criteria (isolated) for depression and the mean score of nine items was reported, namely: irritability (85\%), sleep disturbance $(85 \%)$, self-accusations $(75 \%)$, fatigue $(70 \%)$, sadness (65\%) and body image distortion (65\%). Among the 10 most marked items, the majority were concentrated in symptoms that correspond to affective dysphoric experiences (irritability, self-reproach, sorrow, distorted body image, indecision, feelings of guilt and somatic concern).

Table 3 - Percentage distribution of the participants, mean scores and standard deviation, regarding the predominant quality of life domains

\begin{tabular}{lccc}
\hline \multicolumn{1}{c}{ Predominant domains } & N & $\%$ & Mean score (SD) \\
\hline Domain 1 (Physical) & 8 & 40 & $69,4( \pm 13,64)$ \\
Domain 2 (Psychological) & 4 & 20 & $66,85( \pm 11,77)$ \\
Domain 3 (Social Relationships) & 6 & 30 & $67,5( \pm 18,84)$ \\
Domain 4 (Environment) & 2 & 10 & $60,8( \pm 15,22)$ \\
Total & 20 & 100 & \\
\hline
\end{tabular}

The first aspect evaluated by the application of the WHOQOL-Bref was general satisfaction with the quality of life. Fourteen participants (70\%) rated their quality of life as good, while six participants (30\%) estimated it to be very good. Regarding satisfaction with health, three said they were dissatisfied (15\%), eight were neither satisfied nor dissatisfied (40\%), eight were satisfied $(40 \%)$ and one was very satisfied. It was therefore noted that satisfaction with health was less appreciated than quality of life for participants.

The majority of participants positively evaluated their quality of life. Only one showed divergent scores below the scores of the other participants. The most appreciated domain was the physical and the most compromised was the environment domain (Table 3 ).

Table 4 - Association between research variables, according to the statistical analysis

\begin{tabular}{lllcc}
\hline & \multicolumn{2}{c}{ Variables } & r & p \\
\hline Income & $X$ & Items of the BDI & -0.49 & $0.03^{*}$ \\
Income & $X$ & Psychological domain & 0.47 & $0.04^{*}$ \\
Depression & $X$ & Environment domain & 0.60 & $0.006^{*}$ \\
& & Physical domain & -0.51 & $0.02^{*}$ \\
& & Psychological domain & -0.75 & $0.001^{*}$ \\
Education & & Environment domain & -0.60 & $0.006^{*}$ \\
& & Physical domain & 0.46 & $0.04^{*}$ \\
& & Psychological domain & 0.46 & $0.04^{*}$ \\
& & Environment domain & 0.67 & $0.001^{*}$ \\
\hline
\end{tabular}

* Significant Difference considered to be $p \leq 0.05$

The data summarized in Table 4 correspond to the associations between the research variables that reached statistical significance, using the Spearman correlation coefficient. We did not observe a statistically significant correlation between the items of the BDI, the domains of quality of life and the variables of age and educational level of mother, marital status, current occupation, religion and number of children. The family income variable was negatively associated with the BDI items and positively with the psychological and environment quality of life domains. Also, the psychological, environment and physical domains were positively associated with level of schooling, which follows the trend detected in the association with family income.

\section{Discussion}

Socio-demographic data, such as ages of mother and child, number of children, maternal education, religion and income showed a sample with diverse characteristics. This did not apply to marital status or 
to working activity of the mother, as the majority were caregivers and occupied exclusively with domestic work. Low income may limit families' ability to access resources for care and education and opportunities for recreation and leisure, which are dimensions relevant for quality of life and personal well-being ${ }^{(1)}$.

In relation to occupation, the sample consisted of a group of caregivers devoted full time to their children. To maintain exclusive dedication to care for the child, they channel their energy into the performance of daily activities related to motherhood and housework, with little available for self-care. Perhaps this is the reason the physical domain has emerged as the aspect of quality of life better appreciated. This domain assesses the willingness demonstrated in day-to-day (energy versus susceptibility to fatigue), integrative functions (sleep and rest), mobility, performance of daily activities, dependence on medication/treatment and work capacity(21).

The majority of participants did not reach a number of criteria consistent with the diagnosis of depression, but all reported isolated items at some level. A prevalence of criteria for dysphoria/depression was found in only $15 \%$ of these mothers. Scores lower than 15 indicate criteria of normality or mild depression ${ }^{(19)}$, which is compatible with the general population ${ }^{(23)}$, as was the case for $85 \%$ of the sample. However, a limitation of the findings of this study concerns the fact that the variable relating to the psychiatric history of mothers was not controlled, except through self-report. This can lead to a bias, since mothers with a psychiatric history could show positive results for symptoms of depression.

However, a recently published study about the experiences of mothers (aged 30 to 64 years) of children with autistic disorder, using a qualitative approach, concluded that these mothers have a daily routine that includes domestic chores, personal and family care, prioritizing care involving the child, causing a buildup of responsibilities that eventually contribute to the removal or abandonment of their dreams and desires ${ }^{(24)}$. The results did not corroborate findings in the literature that caregivers of children with chronic conditions are vulnerable to developing psychological difficulties ${ }^{(1-2,5-8)}$. Nevertheless, recognizing the limitation and objectivity of the instruments employed, it is assumed that a complementation using the qualitative approach would add information about the subjectivity of these mothers, not covered in this study.

The participants rated their quality of life as positive. The physical domain, which obtained the highest appreciation, includes questions concerning pain and discomfort, energy and fatigue, sleep and rest, mobility, activities of daily living, dependence on medication or treatment and work capacity.

The environment domain was the least appreciated and consists of the aspects: physical security and protection, home environment, financial resources, health and social care, opportunities to acquire new information and skills, recreation and leisure, physical environment and transportation. This is the domain in which the participants perceive the condition encountered in the environments they circulate in. Although the difference between the scores of all quality of life domains was not significant, it could be that, among the domains evaluated, those that refer to the space for rest and intellectual enrichment are the ones most affected among these participants.

A lower educational level correlated with more depressive symptoms and with a lower total score for quality of life when compared to those mothers with more years of study. It is known that autistic disorder causes various concerns in the families of children ${ }^{(7)}$, especially with regard to the difficulty of self-sufficiency ${ }^{(4)}$. It is assumed that lack of information contributes to ignorance about certain characteristics of the child and, therefore, less clarification regarding how to deal with the son and more family adjustment problems ${ }^{(1)}$.

\section{Conclusion}

Associations were found between criteria for dysphoria/ depression and quality of life domains. Participants with higher financial returns indicated a significantly lower number of items on the BDI and had a higher appreciation of the psychological and environment quality of life domains. Conversely, mothers who filled many items of the BDI obtained lower scores for quality of life. Mothers with higher educational level were also significantly less vulnerable to the criteria for dysphoria/depression and presented higher scores in the psychological, environment and physical domains, consistent with the trend observed with regard to family income.

The low level of family income and the lower assessment of the environment domain compared to other aspects of quality of life denotes lack of financial resources, which could facilitate the payment of an assistant to take care of the child for some time during the day. This would allow the mother to devote herself to work outside or to leisure activities, relaxation and intellectual enrichment. A significant limitation in the 
capacity to take pleasure in life and achieve satisfaction was observed.

The intrinsic limitations in the design of this study need to be recognized. The prevalence of criteria for dysphoria/depression in a minority was found and, as the psychiatric history was not evaluated using specific instruments, it may have been that the participants who scored criteria for dysphoria/depression had such a history.

Considering the obtained results, the condition of the mothers and the complete dedication to the child, we suggest further studies, especially on the variables that did not show to be significant, as well as on the subjective aspects of the mother-child relationship not focused on in this study. Thus, development of the evidence found here may be further discussed.

The systematization of this knowledge can help to support the planning of programs and care services directed at children with autistic disorder, which include the family perspective. In this case, it is necessary to invest in the implementation of a support network for families and to enhance opportunities for recreation and leisure for caregivers of children with pervasive developmental disorders.

\section{References}

1. Fávero MAB, Santos MA. Autismo infantil e estresse familiar: uma revisão sistemática da literatura. Psicol Refl Crít 2005 setembro; 18(3):358-69.

2. Braga MR, Ávila LA. Detecção dos transtornos invasivos nas crianças: perspectiva das mães. Rev Latino-am Enfermagem 2004 novembro; 12(6):884-9.

3. American Psychiatric Association (APA). Diagnostic and Statistical Manual of Mental Disorders, Fourth Edition, Text Revised. Washington, DC: American Psychiatric Publishing; 2002.

4. Klin A. Autismo e síndrome de Aspeger: uma visão geral. Rev Bras Psiquiatr 2006 maio; 28(supl 1):3-11.

5. Lampreia C. A perspective desenvolvimentista para a intervenção precoce no autismo. Estud. Psicol. (Campinas) 2007 janeiro; 24(1):105-14.

6. Blacher J, McIntyre LL. Syndrome specificity and behavioural disorders in young adults with intellectual disability: cultural differences in family impact. J 2006 Mar; 50(3):184-98.

7. Sprovieri MHS, Assumpção FB Jr. Dinâmica familiar de crianças autistas. Arq Neuro-Psiquiatr 2001 junho; 59(2a):230-7.

8. Lewis P, Abbeduto L, Murphy M, Richmond E, Giles N, Bruno L, et al. Psychological well-being of mothers of youth with fragile $X$ syndrome: syndrome specificity and within-syndrome variability. J Intell Disabil Res 2006 November; 50(12):894-904.

9. Vitolo MR, Benetti SPC, Bortolini GA, Graeff A, Drachler ML. Depressão e suas implicações no aleitamento materno. Rev Psiquiatr 2007 janeiro; 29(1):28-34.

10. Fritsch R, González J, Barrientos X, Montt ME, Larraguibel M, González MI, et al. Calidad de la vida familiar y armonía matrimonial en parejas de madres deprimidas. Rev Psiquiatr Clin 2005 março; 42(1):23-31.

11. The WHOQOL Group. The World Health Organization quality of life assessment (WHOQOL): position paper from the World Health Organization. Soc Sci Med 1995 November; 41(10):1403-9.

12. Seidl EMF, Zanon CMLC. Qualidade de vida e saúde: aspectos conceituais e metodológicos. Cad Saúde Pública 2004 março; 20(2):580-8.

13. Andrades Barrientos L, Valenzuela Suazo SV. Quality of life associated factors in Chileans hospitals nurses. Rev Latino-am Enfermagem 2007 maio; 15(3):480-6.

14. Franco GP, Barros ALBL, Nogueira-Martins LA. Quality of life associated factors in Chileans hospitals nurses. Rev Latino-am Enfermagem 2005 março; 13(2):139-44.

15. Marciano ARF, Scheuer CI. Quality of life in siblings of autistic patients. Rev Bras Psiquiatr 2005 January; 27(1):67-9.

16. Talbot A, Hales RE, Yudofsky SC. Tratado de psiquiatria. Porto Alegre (RS): Artes Médicas; 1992.

17. Beck AT, Ward $\mathrm{CH}$, Mendelson M, Mock J, Erbaugh G. An inventory for measuring depression. Arch Gen Psychiatry 1961 January; 4:53-63.

18. Gorenstein C, Pompeia S, Andrade L. Scores of Brazilian university students on the Beck Depression Inventory and the State-Trait Anxiety Inventory. Psychol Rep 1995 October; 77(2):635-41.

19. Gorenstein C, Andrade L, Inventário de Depressão de Beck: propriedades psicométricas da versão em português. In: Gorenstein C, Andrade L, Zuardi, AW, editores. Escalas de Avaliação Clínica em Psiquiatria e Psicofarmacologia. São Paulo: Lemos Editorial; 2000. p. 89-95.

20. Fleck MPA. O instrumento de avaliação de qualidade de vida da Organização Mundial da Saúde (WHOQOL-100): características e perspectivas. Ciênc Saúde Coletiva 2000 janeiro; 5(1):33-8.

21. Fleck MP, Lousada S, Xavier M, Chachamovich E, Vieira G, Santos L, et al. Aplicação a versão em português do instrumento abreviado da qualidade de vida WHOQOL-Bref. Rev Saúde Pública 2000 abril; 34(2):178-83.

22. Associação Brasileira de Empresas de Pesquisa. Critério de Classificação Econômica Brasil. [citado 20 dez 2008]. Disponível em: http://www.abep.org/codigosguias/ABEP_CCEB.pdf

23. Nunes EP Filho, Bueno JR, Nardi AE. Psiquiatria e saúde mental: conceitos clínicos e terapêuticos fundamentais. São Paulo: Atheneu; 2001.

24. Monteiro CFS, Batista DONM, Moraes EGC, Magalhães TS, Nunes BMVT, Moura MEB. Vivências maternas na realidade de ter um filho autista: uma compreensão pela enfermagem. Rev Bras Enferm 2008 maio; 61(3):330-5.

Received: Oct. $9^{\text {th }} 2008$

Accepted: Jun. $18^{\text {th }} 2009$ 